

\section{Sumário}

INOVAÇÃO INSTITUCIONAL E RESISTÊNCIA CORPORATIVA: O PROCESSO DE INSTITUCIONALIZAÇÃO E LEgitimaçÃo do Conselho NaCional de JustiçA .............................................................14 Leandro Molhano Ribeiro e Christiane Jalles Paula

A responsabiLIDADE SOCIAL DA MAGISTRATURA BRASILEIRa: ACCOUNTABILITY E RESPONSIVIDADE EM MEIO À TENSÃO ENTRE O DEVER DE PRESTAR CONTAS E A GARANTIA DA INDEPENDÊNCIA JUDICIAL .30

Marcelo Roseno de Oliveira

THE END OF THE WORLD AS THEY KNEW IT: SHOULD FORMER JUDGES BE DENIED ADMISSION TO THE BAR AFTER THE TRANSITION TO DEMOCRACY?

Stefan Kirchner

CONDICIONANTES E DIRETRIZES DE POLÍTICAS PÚBLICAS: UM ENFOQUE COMUNITARISTA DA TRANSFORMAÇÃO SOCIAL

João Pedro Schmidt

GESTÃo PÚBLICA E PARCERIAS PÚBLICO-PRIVADAS: TEORIA DO ESTADO E TECNOLOGIAS DE GOVERNANÇA DIFUSA PARA CONTROLE SOCIAL

Thiago Souza Araujo, Kinn Peduti de Araujo Balesteros da Silva e Aires Jose Rover

A titularidade dos direitos fundamentais por parte de pessoas jurídicas. A empresa COMO AGENTE DE EFETIVAÇÃO DOS DIREIRTOS SOCIAIS: NOTAS INTRODUTÓRIAS AO DIREITO EMPRESARIAL CONSTITUCIONAL 100

Arnaldo Sampaio de Moraes Godoy e Patrícia Perrone Campos Mello

DA TEORIA OBJETIVA DA DESCONSIDERAÇÃO DA PERSONALIDADE JURÍDICA E OS GRUPOS DE SOCIEDADES SOB A ÓTICA DAS RELAÇÕES DE CONSUMO

Daniel Amin Ferraz e Marcus Vinicius Silveira de Sá

A inversão do ônus da prova e a Teoria da Distribuição Dinâmica: SEmelhanças e inCOMPATIBILIDADES 141

Leonardo Roscoe Bessa e Ricardo Rocha Leite 
A ClÁusula de INTERdição de CONCORRÊNCIA NO DIREITO BRASILEIRO E SUA FUNDAMENTAÇÃo histórica: o Caso da Companhia dos Tecidos de Juta (1914). Notas Sobre SEUS Reflexos NORMATIVOS, DOUTRINÁRIOS E JURISPRUDENCIAIS 157

Arnaldo Sampaio de Moraes Godoy e Daniel Amin Ferraz

Conditional cash transfers (CCT) in Latin America: Analyzing their potentials and Challenges special reference to the Argentine Republic 178 Luciano Carlos Rezzoagli, Gonzalo Chiapello e Florencia Cabrera

A CONTRADIÇÃo ENTRE A REgULAMENTAÇÃo EXISTENTE E A COMPLEXIDADE DOS FATOS REAIS NO CASO DAS DROGAS PARA DOENÇAS NEGLIGENCIADAS 194 Marcos Vinício Chein Feres, Lorena Abbas da Silva, Pedro Henrique Oliveira Cuco e Alan Rossi Silva

A efetividade da lei maria da Penha quanto À orientação SEXual........................... 210 Francisco Antonio Morilhe Leonardo

Transexualidade e o "Direito dos banheiros" no STF: uma reflexão À luz de Post, SIEGEL E FraSER ......................................................................................223 Maria Eugenia Bunchaft

ChINA'S NEW CONCEPT OF DEVELOPMENT FROM THE PERSPECTIVE OF THE SUSTAINABLE DEVELOPMENT GOALS...................................................................................245

Di Zhou

CONTAMINAÇÃo MiCrobIológICA dA ÁGUA: PERSPECTIVAS A PARTIR DO DiÁlOGO ENTRE AS FONTES DO DIREITO 260 Patrícia Maino Wartha, Haide Maria Hupffer, Gustavo da Silva Santanna e Fernando Rosado Spilki

Solar panels in Brazil: a FEASible PUblic POLICY 279 Henrique Pissaia de Souza

UNIDADES DE CONSERVAÇÃO, TERRAS INDÍGENAS E QUILOMBOLAS NO ESTADO DO AMAPÁ: COMO DESENVOLVER UM ESTADO CUJO TERRITÓRIO ESTÁ 70\% PROTEGIDO POR LEIS? .290 Linara Oeiras Assunção

A educaÇão diferenciada como política pública de inClusão social dos Guarani e Kaiowá no Estado do Mato Grosso do Sul 310 Isabelle Dias Carneiro Santos 
ESTADO E RELIGIÃO. O DIREITO CONSTITUCIONAL BRASILEIRO E O CRISTIANISMO: INVENTÁRIO DE POSSIBILIDADES ESPECULATIVAS, HISTÓRICAS E INSTRUMENTAIS

Arnaldo Sampaio de Moraes Godoy e Patrícia Perrone Campos Mello

O RiO E A CIDADE: O DiÁlogo JURÍDico ENTRE O PLANO HÍDRICO E O PLANO DIRETOR .........360 Clarissa Ferreira Macedo D'Isep 


\title{
Conditional cash transfers (cct) in Latin America: Analyzing their potentials and challenges special reference to the Argentine Republic*
}

\author{
Programas sociais de transferência de \\ renda na América Latina: Analisando suas \\ potencialidades e desafios com especial \\ referência à República Argentina
}

\author{
Luciano Carlos Rezzoagli** \\ Gonzalo Chiapello*** \\ Florencia Cabrera****
}

* Recebido em 12/12/2016

Aprovado em 24/12/2016

** Researcher CONICET - National University of Litoral, Argentina . Phd in Public Finance and Tax Law at the University of Salamanca, Spain.Email: lrezzoagli@hotmail.com . Dirección laboral: Candido Pujato 2751. (3000) ciudad de Santa Fe, provincia de Santa Fe, Argentina, Tel. laboral (54) 03424571207 (Centro de Investigaciones, FCJS - UNL).

*** Researcher at the research group of Fiscal Federalism and Territorial Asymmetries (Director Dr. Luciano Rezzoagli ) of the National University of Litoral, Argentina

**** Researcher at the research group of Fiscal Federalism and Territorial Asymmetries (Director Dr. Luciano Rezzoagli ) of the National University of Litoral, Argentina.

\section{ResUmen}

Las transferencias monetarias condicionadas como instrumento financiero de asignación de recursos direccionado hacia sectores sociales vulnerables, fue ampliamente utilizada desde los 90s hasta nuestros días, tanto en América Latina como en países en vía de desarrollo de otros continentes y hasta por algunos países desarrollados. Sin embargo, los problemas que vienen con este tipo de intervenciones requieren un análisis detallado de oportunidad, ejecución, evaluación y control para determinar su legitimidad instrumental sus potencialidades y desafíos. Es un estudio cualitativo, no experimental, lógico - descriptivo analítico.

Palabras claves: desarrollo social, pobreza, finanzas públicas, transferencias monetarias condicionadas, América Latina. 


\section{Resumo}

Programas sociais de transferência de renda foram amplamente utilizados, desde os anos 90 até os nossos días, como instrumento financeiro para alocação de recursos destinados a setores sociais vulneráveis tanto na América Latina como em países em desenvolvimento de outros continentes; inclusive, em alguns países desenvolvidos. Todavia, os problemas que surgem com este tipo de intervenção requerem uma análise detalhada acerca de sua oportunidade, execução, avaliação e controle, para que se possa determinar a sua legitimidade instrumental, suas potencialidades e desafíos. Este é um estudo qualitativo, não experimental, e lógico - descritivo e analítico.

Palavras-chave: desenvolvimento social, pobreza, finanças públicas, programas sociais, transferências monetárias condicionadas, América Latina.

\section{INTRODUCTION}

Latin America is the most unequal region in the world, although it is also the one that has experienced the greatest progress in combating the poverty over the last fifteen years ${ }^{1}$. The economic crisis in 2008/09 became a turning point for the region; since many Latin American Governments did not opt for austerity measures or structural adjustments programs to face the crisis but for maximizing the presence of the public sector and maintaining social investment to tackle the consequences of the crisis in the economic and social field.

In this scenario, co-responsibility programs (intergovernmental transfers for social purposes or directly targeted at certain citizens as beneficiaries) were one of the most significant innovations in policies throughout the continent.

This form of social-protection programs have been developed as an attempt-since its early implementation- to coordinate the objective of reducing and containing the poverty with the concomitant promotion of social cohesion, broadening the scope of traditional social security ${ }^{2}$.

Brazil and Mexico were the two first countries in the region that articulated these kind of initiatives, back in the early 90s; and that today has achieved widespread coverage across Latin America. As figures show, currently twenty countries in the region has put into force some kind of transfer related social program; reaching around 127 million people; allocating $0.4 \%$ of regional GDP3.

The crux for these programs to operate properly is Federal Government coordination; since its important role ranges from the provision of public goods and promotion of welfare to the need to pass tax reforms aligned with the social objectives throughout all the country taking into account regional differences and needs ${ }^{4}$, one of the main discussion revolves around deciding how decisions are made and from which level of government those needs and policies are designed and externalized (whether it is federal or local government) as this raises a lot of issues related to how these programs should be conducted.

The Universal Declaration of Human Rights evidences an early concern about various components of social protection, which back then were gathered and arranged in the International Covenant on Civil and Political Rights.

1 Eclac, report 2015. http://www.cepal.org/sites/default/files/presentation/files/220321_ps_2015_ppt.pdf

2 Cogliandro, G. (2010). El programa Asignación Universal por Hijo y los cambios en los programas de transferencias condicionadas. Fundación Siena.

3 Eclac, report 2015. http://www.cepal.org/sites/default/files/presentation/files/220321_ps_2015_ppt.pdf

4 Eclac, report 2015. http://www.cepal.org/sites/default/files/presentation/files/220321_ps_2015_ppt.pdf 
Likewise, The 1988 San Salvador Protocol states that all OAE's member countries must protect, thorough progressive measures, economic, social and cultural rights in their national legislation so as to ensure the general welfare. The Protocol imposes obligations on the states in terms of labor rights, social security scope, the right to enjoy the highest level of mental, social and physical wellbeing (through the recognition of the right to health, right to adequate nutrition and the right to education) and the states' duty to guarantee improvements in the material living conditions of families. It is in this specific aspect where CCT find their source of legitimacy.

Several countries have constitutional recognition of social rights -examples being the cases of Brazil, Colombia and Argentina, among others- however, only a few of them actually include explicit guarantees of rights in their policies and social protection programs. Also, there are still large gaps in both access and coverage for different population groups ${ }^{5}$. CCT programs are a part of the public, and the same time, social policies that governments enforce in order to face these challenges ${ }^{6}$, that is why they cannot be analyzed outside the sociopolitical and economical context that affects their design and implementation.

As it is logical, it is not the same implementing CCT programs in highly unequal regions as it is in regions with an homogeneous distribution of horizontal opportunities (access to health care, education, public facilities and so on); nor is it the same in a country with a relatively high Gini coefficient (which reflects inequality) as it is in another with a lower one (which shows a high rate of equality), or at least, with a GDP geographical distribution not concentrated in just a small part of the territory. In these latter cases, redistributive policies lose ground against the need of impose more and better incentives for competition and social responsibility.

One of the main challenges for Latin America as a region with high social inequality and therefore with a high concentration of development opportunities in a small part of the population and territory; is the enormous challenge that poses food security, starting from the complexity that means recognizing food as a right for everyone, in a context in which agriculture and natural resources are subject to commodification, environmental degradation and international policies which insist on banking on industrial agriculture and speculative markets within a loose regulatory framework, which leaves nothing but small farmers unprotected and vulnerable people without proper access to food ${ }^{7}$. Inequality, thus, does not only reflects on a huge income gap but also on discrimination against class, race, gender, geographical origin, and so on; which makes it incompatible with our democratic ideals ${ }^{8}$.

When it comes to helping vulnerable people, we must bear in mind that poverty is not only a deficit in material resources but also a context in which decisions are made, which means that it also implies a cognitive burden for the people who suffers it. Individuals who must exert a great deal of mental energy every day just to ensure access to necessities such as food and clean water are left with less energy for careful deliberation on their development opportunities than those who have their basic needs met.

Malnutrition is particularly serious when it takes place in early years of life, since it always emerges in places where low self-esteem and lack of hygiene seal human misery as malnourished often come from places which lacks of drinking water, hot water, sewers and toilets, in short, places which lack of elements that ultimately are human rights.

5 Cecchini, S. et. al. (2015). Instrumentos de protección social: caminos latinoamericanos hacia la universalización, ECLAC, $N^{\circ}$ 136 (LC/G.2644-P).

6 Cecchini, S., \& Martínez, R. (2011). Protección social inclusiva en América Latina: una mirada integral, un enfoque de derechos. ECLAC. http://www.cepal.org/es/publicaciones/2593-proteccion-social-inclusiva-america-latina-mirada-integral-un-enfoquederechos

7 Manos Unidas (2013). Derechos Humanos para construer Igualdad, Boletín 192, http://www.manosunidas.org/sites/default/ files/boletin192.pdf

8 Strapasson, K. and Pamplona, D. (2014): A escolha pública econômica para erradicar a pobreza extrema no Brasil, Revista Brasileira de Politicas Publicas, vol.4 no 2 , pp. $46-48$. 
"Well, in this environment of misery, in which most of poor children are born and raised, which includes the absence of family celebrations, music, colors, joy or any other festivities; sadness and discouragement make their own way among the lack of respect to their own bodies and appearance (lack of bygiene and beauty) and also the lack of value for their own home... I mean, parents of malnourished cannot give joy to their children as they do not actually have it (no one can give what they do not have), so, if we want to help them, we must provide them with not just hot water and hygiene but also affection, understanding, love and education. And as time goes by, we will eventually encourage in them the same virtues, and gradually that "citizen insecurity" - another big evil that comes with bad nutrition-will be extinguished. Gradually we will reap the same we sow".

On the basis of the above, It is no doubts that: ensuring equal opportunities for the population of Latin America is one of the biggest challenges in the region and should be tackled with targeted public policies so as to mitigate the current distressing reality. A very significant novelty in the new IMF rhetoric (2014) is how much importance the organism place on the problem of income inequality; which is not just seen as a matter of social injustice but also as a big obstacle to growth. This "inequality momentum" in the official economic thought evidences a mayor change; bridging a gap between social problems and economic challenges; since previously the social issues were presented as a different category from economic growth-realted issues.

In this regard, as long as Society and States have as their common objective freedom, democracy, social justice and economic progress, Equality shall emerge as an elemental and indispensable common ground ${ }^{10}$. It is important, as well, to remember that the very concept of nation must be understood as a solidarity arc beyond the often diverse and conflicting interests of the society.

According to an study conducted by The Inter-American Development Bank, and directed by Stampini Tornarolli in 2012, in the last 15 years CCT programs have revolutionized the way that social assistance is provided to the poor people around the world. This sort of programs have expanded all the way form Latin America and the Caribbean to Asia and Africa, and even some industrialized countries have adopted them as well. They were introduced for the first time in Brazil and Mexico back in the mid-nineties and by 2011 they had already been implemented in 18 countries in the region, reaching roughly 135 million beneficiaries ${ }^{11}$.

Positive impact assessments shown by public statistics and a decade of sustained economic growth -which has ultimately been reflected on an expanded fiscal capacity- were proven vital for its support ${ }^{12}$. Currently, CCT programs account for over $20 \%$ of their beneficiaries' income and it is estimated that the incidence of poverty would be $13 \%$ higher if they had never been implemented. The largest programs (in Brazil, Colombia and Mexico) have reached a coverage which range from 50 to $55 \%$ of the poorest segments of the society.

\section{CCT and its exploitation; Conditionality as its SPeCific trait.}

This resource is founded on the grounds of an efficient walfare which helps to promote development in vulnerable economic sectors, but not giving money as a gift devoid of control, but in a way that encourages responsible practices in the social receiver sector ensuring that -through the relatively strict control by the grantor agency of the fulfilment of the requirements upon which the grant is conditioned- the needs that originally cause the necessity of the provision, are actually being tackled.

9 Albino, A. (2010), Gobernar es poblar, edición Logos, Buenos Aires, pp. 34 and 35.

10 Oszlak, O. (2010). "Formación histórica del Estado en América Latina. Elementos teórico-metodológicos para su estudio", en: Acuña, C., Lecturas sobre el Estado y las políticas públicas: Retomando el debate de ayer, para fortalecer el actual, ed. Brujas: Buenos Aires, primera edición, pp. 115 - 142.

11 Stampini, M. y Tornarolli, L. (2012). The growth of conditional cash transfers in Latin America and the Caribbean: did they go too far? IDB. http:/ /ftp.iza.org/pp49.pdf

12 Amorim, R. and Chagas, L (2014). A construção de novas políticas sociais: o caso de mato Grosso do Sul . Revista Brasileira de Políticas Públicas, v. 4, n. 1, pp. $114-136$. 
That being said, the additional effect of "encouraging the so called responsible social practices" that this institute has, must be brought to the fore. It is well known that the most disadvantaged sections of the population are also those that carry a serious educational debt. And we are not referring just to the formal-institutional education, but the social education, such as strict compliance with the compulsory school attendance, pregnancy care, medical checks and prevention of disease and so on; all of which are undoubtedly laudable and desirable habits that generate a more responsible and inclusive society, while attacking the reasons of social exclusion in the long run ${ }^{13}$. That is why CCT are supported by those who advocate to a "rights-based" approach to development; which aims to achieve a transformation of power relations among the development actors empowering the right holders, rather than just granting them money.

Not only they seeks to promote inclusion by merely making funds available -as entitlement do- but rather addressing the very causes of exclusion -lack of education and health protection- and its consequences.

The traditional approach revolved exclusively around attacking one single issue: food security as an unmet human need whereas this new model -prevailing in latin america- is set to go even further beyond; cultivating desirable social customs that help to build a better social prospective for the vulnerable social groups; thus, disrupting the cycle of poverty.

Of course we are aware of the fact that most of the people who before the cash transfers entered into force didn't have that behavior, now exhibit it not because they had had an epiphany regarding social responsibility but because of the money, it is also true that meanwhile and as a side effect, CCT sow a sense of "responsibility" in the fulfilment of the beneficiaries' social duties, which in best-case scenario, will persist even when the transfers had been withdrawn.

This is, without a shadow of a doubt, a great advantage of CCT as a mechanism to address the causes of poverty by capitalizing human resources compared with the traditional system that lacks of that "empowerment factor".

We want to make the case that conditional social benefits, as an intended to tool to address poverty, can only be designed form the beginning as a temporary and well targeted measure whose ultimate goal shall be building the social structure required to overcome poverty.

CCTs are not about perpetuating poverty with some sort of third-rate alms but instead about attacking and eventually eliminating it. And the way to do so is by making sure that the requirements for granting them are always met since they -and not the money- are the actual mean to achieve the final goal: zero poverty and social development.

\section{Social Responsibility.}

All CCT programs are generally associated with the idea of certain conditions that have to be met byj beneficiaries or recipients so as to get the cash transfer. These conditions are considered joint responsibility, a term that implies a greater role of beneficiaries in promoting their own welfare. The idea of responsibility or self-help has been important in the development discourse since the early $90 \mathrm{~s}$.

The idea of responsibility involves the notion of reciprocity, in other words, the idea that the obligations are not only imposed on beneficiaries, but also apply to service providers. As an example of this we can name the program Red Solidaria (or "Solidarity Network") from El Salvador, where the responsibilities are detailed in an agreement which must be signed by the head of the family and the service provider, if once chosen the family is willing to take part.

13 Rawlings, L. and Rubio, G. (2003). Evaluating the Impact of Conditional Cash Transfer Programs: Lessons from Latin America. World Bank Policy Research Working, Paper 3119. 
Thus, the government of El Salvador - through the Ministry of Education- should provide basic education to all participant children -who are from 6 to 14 years old- up to $6^{\text {th }}$ grade; and through the Ministry of Health it is set to provide basic health services in hospitals or other health institutions subcontracted exclusively for this purpose. The government is also expected to promote lifelong learning lessons for beneficiary families; and make cash transfer conditional on school attendance of children, child and maternal periodic health checks and immunization for children under 5 years.

On the other hand, families ought to ensure registration and school attendance of their children from 6 up to 14 years old, -which is from kindergarten all the way up to $6^{\text {th }}$ grade-; they have a duty to register for health programs, go on controls of child and maternal health and ensure compliance with the basic health protocols and child immunization. They are also bound to attend training lessons offered for families and spend the money they get on food consumption.

When it comes to deciding who are going to be the beneficiaries of these programs, there are two different approaches to take. One alternative is universal coverage without making any distinction among classes. The other option is a plan targeted exclusively at the poorest therefore most vulnerable sectors of the society; ie. those people who are considered within the range of structural poverty relying not only on income or consumption, but in certain variables that are part of the same problematic phenomenon such as child labor, compliance with compulsory education, access to basic services, job training and any other kind, etc. The decision will depend on the availability of resources and the goals the planner wants to achieve.

Many countries with well-structured programs have had time to improve and refine their targeting systems. In some countries with newer programs, it is likely that improvements are needed. As the variety of countries implementing CCT programs diversifies, we would expect that their targeting mechanism and also their results will also diversify .

Some countries choose universalism instead of targeting, as Bolivia did in the "Juancito Pinto" program for all first graders, whereas, Eastern European countries have already instituted testing system to assess the life standard of the beneficiaries; clearly this system could play a greater role in Africa and Asia than in Latin America. In addition, the results that can be reasonably achieved will vary, depending on context and design features such as the age range covered by the program"14.

The identification and selection of beneficiaries can occur at one or more levels. Targeting can be done by both geographically and also by socioeconomic level of individuals or households. Sometimes the programs are implemented through the identification and selection of regions -municipalities and disadvantaged communes- and the way to reach them is by self-selection (opened a enrollment office, the program covers all of who applied for the benefit). In other cases a second level of identification and selection of households or individuals is used, and the benefits are allocated to those who meet eligibility requirements ( for example, your estimated income is below a certain amount of money) .

Needless is to say that in the implementation of any of the levels of identification and selection of beneficiaries named you can make errors of inclusion and exclusion. Actually it is possible to recognize three different types of error: error for inclusion, error for exclusion and insufficient coverage.

The first occurs when in the process of choosing the beneficiaries some families that actually do not need it, are allowed to receive the transfer (ie. the inclusion of non-poor people who have been included as beneficiaries), the error of exclusion occurs when, for example, a home applies to join the program but is not selected because it is considered not poor, and, thirdly, there is insufficient coverage when the program does not cover an entire target population and that can happen for several reasons: lack of budget, because households do not know the program because (which is lack of publicity) or do not know they are eligible

14 Fiszbein, A., Schady, N., Ferreira, F., Grosh, M., Kelleher, N., Olinto, P.; Skoufias, E. (2014). Conditional cash transfers reducing present and future poverty, World Bank, pp. 86 and 87. 
to apply or because they choose not to participate, among other reasons ${ }^{15}$.

\section{Social AND ECONOMIC EFFECTS OF CCT in RECESSIONARY ECONOMIES.}

Recession, crisis and in general drop in economic growth, had provided fertile ground for the resurgence of this kind of conditional social benefits, above all, in those countries economically less competitive and which carry a bigger debut burden: developing countries.

CCT, as a redistributive budgetary allocation tool, has been widely used in order to ensure an efficient way to channel public resources to low-income sectors.

It is worth noting the tight control that this instrument has been subjected to -in terms of research and studies-; primary focused on assessing the social impact they have had, if any being their main objective to analyse its particular value, in economic terms, for battling social marginalization ${ }^{16}$.

As long as growth is concerned, CCT measures have been proven over and over to be efficient initiatives to boost the overall consumption in any given economy ${ }^{17}$. They are nothing but a clear example of countercyclical polices that governments put into place, trying to increase spending -aggregate demand- in sectors that otherwise would not -or at least no as much- take part in the household consumption expenditure.

In the quest for economic equity -being understood as a fairer economy in the sense of contributing to the development of the society as a whole, and not just a part of $i t^{18}$, CCTs are the traditional Keynesian recipe; transferring money flows from the wealthy portion of the society to the poorest part in order to tackle poverty while encouraging domestic economic activity and consumption.

It has been well noted that the payee of these programs, mostly low income workers or unemployment-population, tend to devote the vast majority of their subsidy to purchase good in the domestic economy rather than saving it, which within the Keynesian logic, has a "multiplier effect" in the economy boosting consumption and consequently investments ${ }^{19}$.

In other words, pocket money provided for the government through CCTs, not only helps a mother to buy a school smock for her kids, but correspondingly it also helps to increase the sales of the company that produce them, thus, you get a rise in expenditure -produced by an expansion of the circulating money- that pulls the real economy up by its bootstraps and generates even more demand -suppliers for instance-.

Most of Latin American countries; have adopted protectionist measures in the wake of the 2008 international crisis, cutting tax rates and providing social programs (ECLAC) -which resulted in more money in the hands of people who didn't use to have saving capacity-, thereby lifting consumption. All of which, has led to a significant inflationist tension; deteriorating the money function as a store of value and generating even more eager to consume, which naturally generates an upward trend in prices.

Many countries had succeeded in reducing poverty and inequality and had improved social development indicators through conditional cash transfers programmes. In Brazil, for example, these programs have re-

15 We recommend to the work of Benedetti, Faraj, Ibarrarán and Villa (2014) to dig deeper into targeting methods and error estimation.

16 Rawlings, L. and Rubio, G. (2003). Evaluating the Impact of Conditional Cash Transfer Programs: Lessons from Latin America. World Bank Policy Research Working, Paper 3119.

17 Macours, Karen, Patrick Premand, and Reno Vakis (2011). “Transfers, Diversification and Household Risk Strategies: Experimental Evidence with Lessons for Climate Change Adaptation.” Working Paper, Paris School of Economics.

18 Coraggio, J. L. (2002). La economía social como via para el desarrollo social, Red de Políticas Social Urbared, UNESCO.

http://www.redetis.org.ar/media/document/economiasocialcoraggio.pdf

19 Fiszbein, A., Schady, N., Ferreira, F., Grosh, M., Kelleher, N., Olinto, P.; Skoufias, E. (2014). Conditional cash transfers reducing present and future poverty, World Bank. 
ceived much attention in recent years. Also, these programmes have contributed to improving the economic development and the material living conditions of the beneficiaries. Nevertheless, CCT's were not effective in reducing the number of poor and extreme poor, because Brazil's Governments need to review the criteria used to identify them ${ }^{20}$. In consecuense, it should be consistent with the daily monetary amount established by the UN tohuman survival.

As noted by World Bank in 2014 ${ }^{21}$, in general terms, CCTs have led to increase consumption in low-income families. As a result of that, in some cases, conditional transfers succeeded in reducing poverty among their beneficiaries; particularly when the amount of money provided was generous, well-targeted and structured so as not discourage beneficiaries from finding, on their own, other ways to overcome their precarious situation.

So, the main idea behind CCTs -as a countercyclical measure when applied as such- is that: by empowering people economically; the vulnerable sectors targeted by these measures had more disposable income and consequently domestic expenditure soared. However, in countries such as Colombia, it has been proven that the desirable consumption-incentive effect, could be more subtle than expected. Partly because the new influx of money -which is actually taken from the public treasure and re directed to poor families-, in some cases only makes up for the loss of income from those illegal activities which had to be stopped so as to entitle the family for the benefit (for example child labor) and secondly because often a big part of that liquid money is allocated to debt payments -financial consumption that does not reflect on the real economy of goods- or in the case of those beneficiaries who have a better economic situation it is just saved. One might argue here -and probably would be right-, that those who reveal a saving capacity should not be entitled for the benefit in the first place.

But it is not only the increase in the consumption what matters, but also the "composition of this consumption" 22 . There is evidence that households receiving CCTs, tend to spend most of it on food; and above all on those that have best nutritional quality from the basic basket of food than those who have a similar income but do not get the benefit ${ }^{23}$.

Following the same idea, it is noteworthy the benefits CCTs have, in terms of access to the formal educational system, in most of the cases, public schools. As the World Banks itself says; "In all countries, school enrollments has increased among the CCT's beneficiaries, especially in the case of poor children whose enrollment rates were lowest before these programs put into force". In countries like Bangladesh, Pakistan and Turkey where girls school enrollment were lower than their male counterparts, CCTs have helped to reduce the gender gap.

Same effects are replicated in the use of public preventive health system, in those countries that actually have $\mathrm{it}^{24}$. As a Lisa Feranld and colleagues' research concluded by analyzing the effects of Mexico's "Oportunidades Program" on the long-run; "CCT are effective means in order to increase the usage of health services and so as to improve the indicators of the overall nutritional status in children" 25 .

20 Rocha, M., Fontes, R., Mattos, L. and Cirino, J. (2014): Programas sociais brasileiros e sua relação com a pobreza, a desigualdade e o desenvolvimento. Revista Brasileira de Politicas Publicas, vol.4 nº 1, pp. $138-153$.

21 Fiszbein, A., Schady, N., Ferreira, F., Grosh, M., Kelleher, N., Olinto, P.; Skoufias, E. (2014). Conditional cash transfers reducing present and future poverty, World Bank.

22 Attanasio, O. y Mesnard, A. (2005). The Impact of a conditional cash transfer programme on consumption in Colombia, IFS, p.17. 23 Fiszbein, A., Schady, N., Ferreira, F., Grosh, M., Kelleher, N., Olinto, P.; Skoufias, E. (2014). Conditional cash transfers reducing present and future poverty, World Bank.

24 Jones, N; Samuels, F;Gisby, L and Presler-Marshal, E. (2011). Rethinking cash transfers to promote maternalhealth: good practice from developing countries, ODI, p. 2; Huntington, D. (2010). The impact of conditional cash transfers on health outcomes and the use of health services in low- and middle-income countries. The WHO Reproductive Health Library; Geneva: World Health Organization. 25 Fernald, L., Gertler, P. and Neufeld, L. (2008). Role of cash in conditional cash transfer programmes for child health, growth, and development: an analysis of Mexico's Oportunidades, Lancet, p. 36. 


\section{The situation in Argentina.}

Particularly in the case of Argentina, CCTs programs first showing date back to 1996 with the implementation of "Plan Trabajar" ("Working Program"). Back in 2001, in the wake of one of the worst financial crisis Argentina had ever faced, the program was set to reach even more people by broaden the scope of beneficiaries and becoming from that point on "Plan Jefes y Jefas de Hogar Desocupados" ("Head of unemployed households program"). Originally it gave a fixed amount of money (150 \$ which back then was roughly the equivalent of 50 US\$) to nearly two million unemployed people, and at its height -in 2003- it got to transfer 3.052 million pesos or 1 billion dollars ${ }^{26}$.

Since 2004 a number of programs were lunched in the hope of taking on the at-the-time high unemployed population in the country. Among them were "Plan Familias", "Plan Manos a la Obra" and "Plan de Seguros, Capacitacion y Empleo". Former "Plan Trabajar" recipients -which was in process of disintegration- made up most of the universe of beneficiaries of those brand-new programs.

What stood out of these new measures, was that in order to get the money those who were entitled to, had to fulfill some requirements, among which were to perform some kind of public work -certain amount of hours per week- or attend training programs which hopefully would give them means to ultimately get an actual job. That's why these incentives were also called plans of "co-responsibility".

During the course of 2009; two new programs were put into force under the direct supervision of the "Ministry of Social Development" and the "National Social Security Administration"; first was the "Programa Ingreso Social con Trabajo", and then the "Asignacion Universal por Hijo para la Proteccion Social".

"Argentina Works" -so was it called-, which emerged in 2009, had among its goals guarantee social inclusion by means of work, training from a holistic prospective and the promotion of social cooperation. Its main target was households with no income from either work nor pension, retirement or any other social program.

The implementation financed by federal funds, was carried out through a complex articulation between local government (though different departments that perform public services) and the beneficiaries who were organized in cooperatives of 60 people. This method of distribution aims to fulfill one of the pillars of the program; an actual work activity in a municipal office as a condition required so as to get the social benefit; which accounted for a sum of \$ 1200 (US\$150) that was deposited monthly in an individual and personal bank account created for this purpose and with a specific taxation framework.

Following three years of implementation; the benefit raised by introducing two new payments made by the government, one was a "Plus" for good performance and productivity $\$ 300$ (us\$35) and another awarding attendance -the so-called "presenteeism", when people who are ill and distracted show up for work- for $\$ 250$ (US\$30).

The social intervention of this program is boosted by a wide range of educational and health components. As a part of the participation in the program, beneficiaries not just receive money but also may choose to access to some kind of educational facility in order to study primary or secondary school or enroll in a training course for a specific trade or job; and participate in conferences on prevention and promotion of good helath. These are pre-conditions, admission criteria or monetary conditionalities set and required by the program.

However, the inciative that had the greatest impact in terms of CCTs in Argentina was the "Assignation Universal por Hijo" (Universal child care benefit); implemented by the executive action PEN 1602/9, in october, 2009. The plan began to be implemented during the fist quarter of 2010 with the main objective

26 Cogliandro, G. (2010). El programa Asignación Universal por Hijo y los cambios en los programas de transferencias condicionadas. Fundación Siena, pp. $4-7$. 
being to compensate and improve the income in those families whose parents were working under the table or simply were not adequately registered so that they were not entitled to any kind of child assistance provided by the government (Argentine Ministry of Economy, official page).

This benefit; as many other similar measures implemented in the continent during those years, were focused on protecting children in need who belong to poor households, providing a new influx of money to their parents so as to help them to afford all the costs that raising their kinds pose.

In mid-april 2011, the creation of "Universal Pregnancy Care Benefit"; which was intended to reduce infant mortality, expanded the benefit to pregnant woman from the 12 th week of gestation onwards as long as the they go through all pre-natal controls required by the government.

While its true that this new circulation of money generated as a result of the implementation of the program could actually generate tangible opportunities to reduce poverty and social exclusion, it is also important to highlight that if used discretionary, could result in deepening the gap of inequality. That is why the criteria used to grant the benefit -deciding who is going to be entitled to get the money- become such an important issue. Those criteria often laid out following moral judgments and government evaluations are worth analyzing.

As long as the selection of beneficiaries remain constrained to those in situation of chronic poverty, it is unlikely that the increased coverage could become a problem. Structural poverty varies little over time and required long-term interventions. The long term goal of CCTs is to ensure that children of beneficiary households get an educational level which allows them to make their way out of poverty; thus getting rid of the need for the next generation to receive social assistance. Under this logic, entitled households would "graduate" from the program when their children get their high school degree and have a decent job.

In Argentina, as in other countries in the continent, we can say that there is some kind of paradox which goes as follow: nobody would argue the importance this programs have in national quantitative terms; but the lack of coordination between the federal government and the local ones, result in qualitative regional issues which revealed as difficult to address. Hence, as we asses the effectiveness of this measure; we can easily appreciate an important reduction in poverty and indigence at a federal level, however, if we take a closer look at a local level we can also glimpse a huge disparity among the regions make up the country.

Although Argentina has a large territory (roughly two hundred million eight thousand square kilometers), it is a distinctive feature of the country to have a high concentration of the overall population located in a reduced part of the territory, mainly for natural and human reasons. So much so, that $66.7 \%$ of the country's population lives in the provinces of Buenos Aires (39\%), Cordoba (8.2\%), Santa Fe (8\%), Mendoza (4.3\%) and in Autonomous City of Buenos Aires (7.2\%). The result being a couple of mayor cities highly populated in contrast to vast areas of the territory with really low population rates. For instance, while the City of Buenos Aires has a population density of 14.450,08 inhabitants per square kilometer, there are some provinces in which the density is under one person per square kilometer.

Going further in the analysis, needless is to say that access to formal education is another important variable with respect to the analysis of horizontal equality. It is one of the indicators that more clearly shows the contrast and imbalances among Argentine regions, from the most populated to medium or low density areas. In this regard, it is important to note that while in the Autonomous City of Buenos Aires (CABA) $82 \%$ of the population attended and completed the primary level; in three northern provinces such as Corrientes, Chaco and Misiones, the percentage drops to $56.1 \%, 53.6 \%$ and $51 \%$ respectively.

On the other hand, regarding the assistance to educational institutions between 15 and 17 years old, CABA redisplays the highest levels reaching $90.5 \%$, being only surpassed by Tierra del Fuego with $94.8 \%$. While in Santiago del Estero and Misiones, only $66.5 \%$ and $71.6 \%$ respectively attend to school.

In this line, and if we bring all the argentine provinces into comparision, we can conclude that the average levels of completion of secondary are manifestly disparate but without a steep slope variance or 
exception, being the main reason of that, as seen from the correlated analysis, the Asginacion Universal por Hijo -Universal Child Allowance-.

Precisely, one of the greatest social gains driven by the federal government is the program called "Universal Child Allowance", which is an actual right granted by the government children of unemployed parents or parents working in the informal economy who do not make enough money to meet their basic need determined by the social minimum wage.

It also apply for children of social monotributistas , domestic workers, seasonal workers during the period of reserve position or perceive any of the following plans: Argentina Trabaja, Manos a la Obra, Ellas Hacen, Programa de Trabajo Autogestionado, Jóvenes con más y mejor trabajo, Programa Promover la Igualdad de Oportunidades y Seguro de Capacitación y Empleo.

The payment of the Universal Child Allowance requires annual accreditation of schooling enrollment and health checks for children. It is paid to people under 18 years old to a maximum of 5 children per family, giving priority to disabled children and the youngest. It is paid to one parent giving priority to the mother of the beneficiaries .

This is a game-changer program in the government action aimed to solve the problem of youth empowerment and class differences betting heavily to achieve a more just and egalitarian society. This aims to generate ideal conditions to break one of the main mechanisms of intergenerational transmission of poverty. However, without detracting from the important progress that this program represents, there are at least two issues to be re-considered or re-discussed to ultimate address the unequally response to exogenous variables such as the place of origin or habitability:

The first has to do with the focal axis, because it is focused on the recipients without taking into account neither the provision nor the quality of the service catered by the provider; it is indisputable that it is an important measure to alleviate the situation of vulnerability of children and adolescents and also to improve on the income of such households in every corner of the country. Now, we must work to not be limited solely to demand compliance and improvement; also quality / quantity of the supply is needed to be taken into account.

The key problem of inequality in education also lies in the quantity but especially in the quality of it. If there is not enough investment in the public system of education, which is the only one that can narrow the gap between rich and poor, the effort will always be insufficient, above all considering that this is a federal program addressing a problem that, according to the argentine constitution, belongs to the provinces (although the Nation collaborates with specific programs, primary and secondary education is decentralized to subnational governments, being they the responsible for finding funding).

This, coupled with the fact that the easiness of access to public educational institutions varies depending where one lives (village, town, municipality, province, region) and infrastructure available, thus the quality of service delivered is fundamentally uneven and changes according to the place where we put the focus on; it is not the same in rich regions than in poor ones, so the actual possibility for the people to take advantage of the educational resources provided by the government is unequal depending upon the place where one lives. This is not just about giving an opportunity, but also giving opportunities to the opportunity, which means nothing but working hard and in a coordinated manner to boost and size the endogenous capacities of the public and private institutions that provide the service.

The second issue, invites us to an even deeper reflection, and related to an analysis that although we will not develop in this point, believe is worth noting. Behind the criticism of redistribution that these plans tend to generate among the population and others undercover in concepts of freedom of choice, economic self-determination, federalism and competitiveness; it also common to hear cowardly voices mainly from discriminatory groups which instead of thinking about strengthen the system, advocate an alleged respon- 
sibility for the poor to overcome their current condition as though they had had the chance, and would had deliberately rejected.

Moreover, this responsibility can transcend the household level and be regarded as an element of social or cultural setback that holds the country growth back, since poverty would be seen as an obstacle to such goal. Under this logic, poor people would end up being responsible for their condition, and for the lack of growth.

\section{Final CONSIDERATIONS}

CCTs have resulted in significant reductions in poverty rates among beneficiaries, especially when the amount of money provided was enough to meet the basic needs, well targeted and structured in a way that does not discourage recipients from carrying out other individual actions to make their way out of poverty.

The system as such, requires not only of a proactive government committed to collect all the tax resources needed to pay the benefits that grants, but also of government that provide all the necessary accessories to ensure that the conditional services are provided in a proper manner ${ }^{27}$.

There is no point in requiring beneficiaries to complete the vaccination calendar, if once they go to the clinic to do so, end up finding out that there are no vaccine available or that they have been exhausted.

The fundamental weakness that threatens this kind of program is the -often in Latin-American- low quality of the services whose observance is required for the beneficiaries to get the money. For instance poor educational structure or low quality health services result in nothing but a scant improvement of beneficiaries' life status.

It is no doubt that in order to be effective, CCTs must be implemented in the context of a smart and well planned policy, well targeted -avoiding what otherwise would be a waste of public resources-, placing enough investments in order to ensure a public infrastructure enough for the services to be provided adequately and as a corollary, making sure that measure itself is always regarded as temporary; ultimately aimed at eradicating poverty.

This state-owned infrastructure required, or as we called -"surrounding public structure"- understood as the governmental framework surrounding the provision itself giving material support to the conditionality is vital for the programs to succeed, and raises the necessity to discuss a broader vision where all the political measures required are taken, the money needed is allocated, the infrastructure built and all this in the context of coordination between the local and federal government in all the parts of the decision making process.

A clear example of a failure in the state structure than ended up threatening and eroding the ultimate goals of the CCTs, is what happened in Brazil during the decade of 1990-2000 with two twins programs, which shared similar goals, but due to the disparate implementation, reached substantially different results.

The only federal CCT program in place by the end of the nineties in Brazil was the "Program for the Eradication of Child Labor " ( PETI), which coexisted with a program administered at a local level called "Bolsa Escola" (BE).

The aim of the first one was, as its name implies, to reduce child labor especially in those activities that posed a danger to health; which was to be achieved through an increase in school attendance of these children in early labor exploitation condition .

27 Strapasson, K. and Pamplona, D. (2014): A escolha pública econômica para erradicar a pobreza extrema no Brasil, Revista Brasileira de Politicas Publicas, vol.4 nº 2, pp. $61-63$. 
Meanwhile, the goal of "Bolsa Escola" was more limited in the sense since it only recognised as the ultimate goal to maximize school enrollment.

Regarding this case, Fábio Veras Soares pointed out the following paradox ${ }^{28}$ : although both programs proved to be successful in their objectives to increase students in classrooms, only PETI had a particular additional effect of educing child labor ${ }^{29}$.

The question that arises here is: why Bolsa Escola, unlike PETI, did not have as a side effect reducing child labor, even when both of them increased enrollment and attendance?

A distinctive feature of PETI was that besides the money for the benefit it provided resources to the participating municipalities that were set to be devoted to offer extra-curricular subjects in order to keep the kids busy in classrooms throughout the day, neutralising the possibility of them to be used as work force.

Since these extra curricular activities were widely used by students, child labor declined markedly, side effect that was not seen in Bolsa Escola that lacked such transfers.

All this clearly shows that in order to lay out a successful conditional monetary benefit, the analysis can not pivote only on the amount of money given through benefit, but also a overall comprehensive review should be directed at finding means to reinforce the surrounding state structure that ensures the effectiveness of the conditionality's and serves as a basis for empowering beneficiaries, while working as a hotbed of social practices sought after.

It must be demystified this idea that public social security expenditure only helps those who are entitled to the benefit. The object of this work has not been nothing but to demonstrate that the whole society benefits from them. Not only for the economic development boosted by them but also from the perspective of social inclusion generated, these last two concepts being often reluctant to share the same reality.

The results probably wouldn't be as fortunate if these programmes are seriously evaluated. In order to defend its own actions, Governments prefer to carry on them without making a serious evaluation. In conclusion, there has been innovation in social policy and considerable resources have been devoted to this end. In spite of this, in those cases where the evaluation showed that programmes do not reach the expected results, relevant measures were not taken at all.

The programmes that have appear in the last 15 years, emerge in order to fight against poverty, and no longer in other social policy dimension, such as education or health. It is important to point out that transferring resources thorugh CCTs is simply not enough to overcome poverty. On the contrary, anessential requirement is to provide poor people with the abilities and skills in order to be part of economic and social life.

\section{BIBLIOGRAPHY}

Albino, A. (2010), Gobernar es poblar, edición Logos, Buenos Aires.

Amorim, R. and Chagas, L (2014). A construção de novas políticas sociais: o caso de mato Grosso do Sul . Revista Brasileira de Políticas Públicas, v. 4, n. 1, pp. 114 - 136.

Attanasio, O. y Mesnard, A. (2005). The Impact of a conditional cash transfer programme on consumption in Colombia, IFS. www.ifs.org.uk/edepo/rs_fam02.pdf

28 Soares, F. (2004). Conditional Cash Transfers. A Vaccine against Poverty and Inequality? IPC-IG collections of One Pagers. International Policy Centre of Inclusive Growth.

29 Cardoso, E and Souza. (2004). The impact of Cash Transfers on Child Labor and School Attendance in Brazil. Mimeo. 
Cardoso, E and Souza. (2004). The impact of Cash Transfers on Child Labor and School Attendance in Brazil. Mimeo.

Cechini, S (2009). Do CCT Programmes work in low-income countries? International Policy Centre for Inclusive Growth, United Nations Development Programme.

Cecchini, S., \& Martínez, R. (2011). Protección social inclusiva en América Latina: una mirada integral, un enfoque de derechos. ECLAC. http://www.cepal.org/es/publicaciones/2593-proteccion-social-inclusivaamerica-latina-mirada-integral-un-enfoque-derechos

Cecchini, S. et. al. (2015). Instrumentos de protección social: caminos latinoamericanos hacia la universalización, ECLAC, Nº 136 (LC/G.2644-P).

Cogliandro, G. (2010). El programa Asignación Universal por Hijo y los cambios en los programas de transferencias condicionadas. Fundación Siena.

Coraggio, J. L. (2002). La economía social como via para el desarrollo social, Red de Politicas Social Urbared, UNESCO, http://www.redetis.org.ar/media/document/economiasocialcoraggio.pdf

Cruces, G, Gasparini, L. (2010) Los determinantes de los cambios en la desigualdad de ingresos en Argentina. Evidencia y temas pendientes Serie de Documentos de Trabajo sobre Políticas Sociales No 5.

De Ferranti, D., Perry, G., Ferrera, F. y Walton, M. (2004): Desigualdad en América Latina. ¿Rompiendo con la historia?, Banco Mundial- Alfaomega.

Fernald, L., Gertler, P. and Neufeld, L. (2008). Role of cash in conditional cash transfer programmes for child health, growth, and development: an analysis of Mexico's Oportunidades, Lancet 327:828-37.

Fiszbein, A., Schady, N., Ferreira, F., Grosh, M., Kelleher, N., Olinto, P.; Skoufias, E. (2014). Conditional cash transfers reducing present and future poverty, World Bank.

Huntington, D. (2010). The impact of conditional cash transfers on health outcomes and the use of health services in low- and middle-income countries. The WHO Reproductive Health Library; Geneva: World Health Organization.

Jones, N; Samuels, F; Gisby, L and Presler-Marshal, E. (2011). Rethinking cash transfers to promote maternalhealth: good practice from developing countries, ODI. http://www.academia.edu/6566089/Rethinking_cash_transfers_to_promote_maternal_health_good_practice_from_developing_countries

Macours, Karen, Patrick Premand, and Reno Vakis (2011). "Transfers, Diversification and Household Risk Strategies: Experimental Evidence with Lessons for Climate Change Adaptation.” Working Paper, Paris School of Economics.

Manos Unidas (2013). Derechos Humanos para construir Igualdad, Boletín 192, http:/ /www.manosunidas. org/sites/default/files/boletin192.pdf

Oszlak, O. (2010). "Formación histórica del Estado en América Latina. Elementos teórico-metodológicos para su estudio", en: Acuña, C., Lecturas sobre el Estado y las políticas públicas: Retomando el debate de ayer, para fortalecer el actual, ed. Brujas: Buenos Aires, primera edición, pp. 115 - 142.

Rawlings, L. and Rubio, G. (2003). Evaluating the Impact of Conditional Cash Transfer Programs: Lessons from Latin America. World Bank Policy Research Working, Paper 3119.

Rocha, M., Fontes, R., Mattos, L. and Cirino, J. (2014): Programas sociais brasileiros e sua relação com a pobreza, a desigualdade e o desenvolvimento. Revista Brasileira de Politicas Publicas, vol.4 no 1, pp. 138 - 153. 
Soares, F. (2004). Conditional Cash Transfers. A Vaccine against Poverty and Inequality? IPC-IG collections of One Pagers. International Policy Centre of Inclusive Growth.

Soares, S. and Pianto, D.M. (2003). Use of Survey Design for the evaluation of Social Programmers: The PNAD and the Program for the Eradication of Child Labor in Brazil. University of Illinois.

Susmel, N. (2012), Argentina: Pobreza, desigualdad de oportunidades y políticas públicas en América Latina, Konrad - Adenauer - Stiftung.

Stampini, M. y Tornarolli, L. (2012). The growth of conditional cash transfers in Latin America and the Caribbean: did they go too far? IDB. http://ftp.iza.org/pp49.pdf

Strapasson, K. and Pamplona, D. (2014): A escolha pública econômica para erradicar a pobreza extrema no Brasil, Revista Brasileira de Politicas Publicas, vol.4 no 2, pp. 46 - 64.

Tejerina, L. and Pizano, V. (2016): Programas de Transferencias Monetarias Condicionadas e Inclusión Financiera, BID, tecnical note n $^{\circ}$ IDB-TN-1140. https://publications.iadb.org/bitstream/handle/11319/7958/ Programas-de-Transferencias-Monetarias-Condicionadas-e-Inclusion-Financiera.pdf? sequence $=4$

Veras Soares, F. y Britto, T. (2007) Growing Pains: Key Challenges for New Conditional Cash Transfer Programmes in Latin America, IPC-IG collection of One Pagers, International Policy Centre for Inclusive Growth.

Weller, J. y Miranda, G. (2014). Coyuntura laboral en América Latina y el Caribe. Los programas de transferencias condicionadas y el mercado laboral. Número 10. CEPAL/OIT. 
Para publicar na revista Brasileira de Políticas Públicas, acesse o endereço eletrônico www.rbpp.uniceub.br

Observe as normas de publicação, para facilitar e agilizar o trabalho de edição. 